\title{
Monitoring and Impact Evaluation System for Arsenic Mitigation Interventions - Arsenic Contamination Areas of Pakistan
}

\author{
Islam-ul-Haque ${ }^{1}$, Muhammad Nasir ${ }^{2}$ \\ ${ }^{1}$ Eco-Logical Sustainability Through Environment Protection Services (Eco-STEPS), Inc, Islamabad, Pakistan \\ ${ }^{2}$ Plan Pakistan International, Islamabad, Pakistan
}

\section{Email address:}

islamhaq3@yahoo.com (Islam-ul-Haque),m_nasir21@yahoo.com (M. Nasir)

\section{To cite this article:}

Islam-ul-Haque, Muhammad Nasir. Monitoring and Impact Evaluation System for Arsenic Mitigation Interventions - Arsenic Contamination Areas of Pakistan. International Journal of Environmental Monitoring and Analysis. Special Issue: Ground Water Arsenic Contamination and Action Plan for Mitigation. Vol. 3, No. 3-1, 2015, pp. 67-78. doi: 10.11648/j.ijema.s.2015030301.18

\begin{abstract}
Drinking water arsenic contamination has emerged as a big nuisance to public health and approximately 137 million people around the world consume arsenic contaminated water, exceeding the WHO threshold of $10 \mu \mathrm{g} / \mathrm{L}$. In Pakistan context, various arsenic mitigation initiatives were undertaken by different NGOs and government departments which were confined to one time measure and resultantly turned to be un-sustainable. Continuous surveillance of drinking water sources is crucial for the well being of humans for which systemised procedures for regular monitoring of the arsenic contaminated water sources has been evolved. Identifications of contaminated water sources for random and blanket arsenic testing surveys will make the monitoring \& evaluation process more reliable and prudent. Grid system approach for taking water samples has been discussed and evolved which yield meaningful results. For field test validation, $10 \%$ of water samples are recommended to be tested in the laboratory by using atomic absorption spectrometer (ASS). Well thought out institutional arrangements / linkages have been evolved for achieving government buying which is necessary to make the monitoring and evaluation process sustainable. Though, the donors and NGOs have played an important role in addressing the arsenic contamination issues in many countries, including in Pakistan, yet the ultimate ownership for the success of interventions lies with the government and its line departments.
\end{abstract}

Keywords: Arsenic Testing Kits, Monitoring \& Impact Evaluation, Water Samples

\section{Introduction}

Arsenic contaminated water has proved to be slow poisoning process for the mankind and approximately 137 million people around the world, with 90 million people in Bangladesh and China alone, consume arsenic contaminated water, exceeding the WHO threshold of $10 \mu \mathrm{g} / \mathrm{L}$ (Unicef, 2008). In Pakistan, ground water arsenic contamination was identified during 1996 and basing on this revelation, following arsenic contamination mitigation actions were taken;

\subsection{Preliminary Arsenic Contamination Investigations, 1999-2001}

From Nov. 1999 to Jan. 2001, the Pakistan Council of Scientific and Industrial Research (PCSIR), and the Pakistan
Council of Research in Water Resources (PCRWR) carried out a preliminary investigation on the prevalence. Of the 8,712 samples, nine percent had arsenic above the WHO guideline value of $10 \mathrm{ppb}$ and 0.70 percent of samples had arsenic concentrations above $50 \mathrm{ppb}$. However, analysis of 848 validation samples (10 percent of total samples) by Atomic Absorption Spectrometer (AAS) revealed that almost 30 percent of samples had arsenic concentrations over $10 \mathrm{ppb}$ and seven percent above $50 \mathrm{ppb}$. It should be noted that laboratory results obtained by AAS are thought to be more accurate than those obtained using Merck field testing kits. The results by province are presented in Table 1 .

Results shown in Table 1, indicates that arsenic contamination is prevalent mainly in Punjab and Sindh provinces, where over 11 percent of field samples revealed an arsenic level above $10 \mathrm{ppb}$ and 0.6 to 1.4 percent samples over $50 \mathrm{ppb}$. NWFP and Baluchistan had comparatively little 
arsenic contamination, except one district in KPK province

of arsenic over $50 \mathrm{ppb}$ (NAPAM 2005).

(Mardan) for which laboratory results indicated the presence

Table 1. Results of national survey for arsenic contamination.

\begin{tabular}{llllllll}
\hline \multirow{2}{*}{ District } & \multicolumn{2}{l}{ Total Samples (No.) } & >10 ppb (\%age) & \multicolumn{2}{c}{ (50 ppb (\%age) } \\
\cline { 2 - 7 } & Field & Lab & Field & Lab & Field & Lab \\
\hline Baluchistan & 619 & 71 & 1.30 & 1.40 & 0.0 & 0 \\
NWFP & 1560 & 156 & 0.30 & 22.0 & 0.0 & 0.6 \\
Punjab & 4315 & 428 & 12.2 & 36.0 & 0.60 & 9.0 \\
Sindh & 2218 & 193 & 11.0 & 26.0 & 1.40 & 10 \\
Total & 8712 & 848 & 9.0 & 28.0 & 0.70 & 7.0 \\
\hline
\end{tabular}

\subsection{Arsenic Mitigation Activities - (2002-04)}

Basing on the findings of preliminary investigations, national survey for arsenic testing was launched and the prevalence of arsenic contamination in Pakistan (NAPAM 2005) during national survey (2003-04) is shown in table-2;

Table 2. Summary of national survey (2003-04) results on arsenic contamination.

\begin{tabular}{lllllll}
\hline & \multicolumn{2}{l}{ Total Sample (No.) } & \multicolumn{2}{c}{$>$ 10 ppb(\%age) } & \multicolumn{2}{c}{$>\mathbf{5 0}$ ppb(\%age) } \\
\cline { 2 - 7 } & Field & Lab & Field & Lab & Field & Lab \\
\hline Punjab & 28,898 & 4,611 & 32.5 & 31.4 & 10 & 9 \\
Sindh & 67,556 & 4825 & 24 & 36 & 7.8 & 17 \\
Pakistan & 96,454 & 9,436 & 27 & 34 & 9 & 13 \\
\hline
\end{tabular}

The field results compiled at national level showed $27 \& 9$ percent of water sources had arsenic contamination over 10 $\mathrm{ppb}$ and $50 \mathrm{ppb}$ respectively while lab results showed much higher arsenic contamination of $33 \& 13$ percent over $10 \mathrm{ppb}$ and $50 \mathrm{ppb}$ respectively. However, the situation is even worse in certain teshils/talukas showing over one third of samples over $50 \mathrm{ppb}$. Similarly in certain union councils (e.g. Agra in Taluka Gambat in district Khairpur) almost 75 percent of water sources had contamination over $50 \mathrm{ppb}$ and 93 percent over $10 \mathrm{ppb}$, with highest recorded concentration of $972 \mathrm{ppb}$ (Tameez et al 2004).

National action plan for arsenic mitigation was developed in 2004. The findings of the action plan could not be transformed fully on ground and arsenic contamination problem is still plaguing the lives of affected population/communities. Lot many activities were planned which were partially undertaken and the arsenic contamination in Pakistan is still growing in scope and complexity. Arsenic contamination in Pakistan has been, graphically shown in figure-1, below;

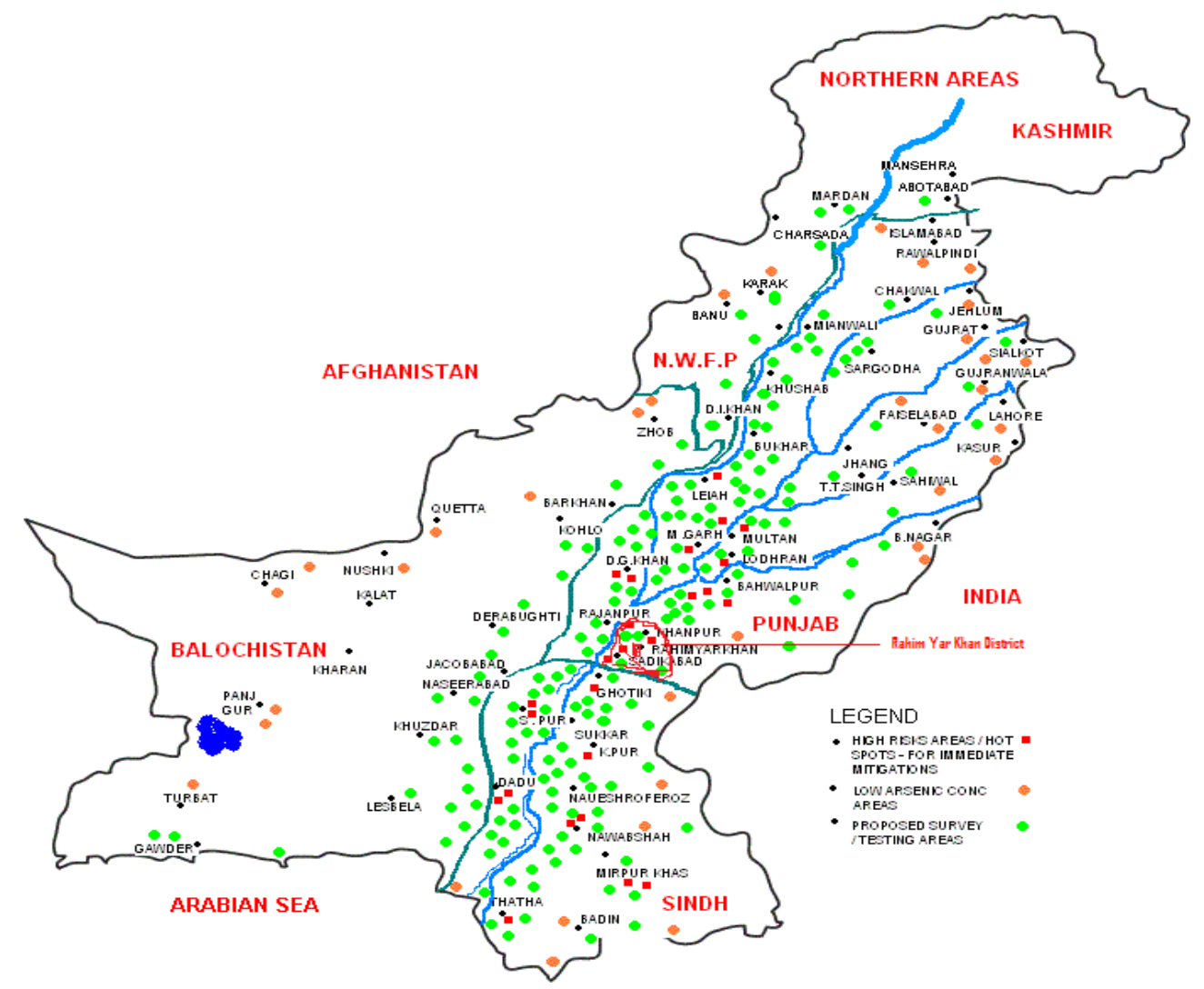

Figure 1. Pakistan map, showing arsenic contamination. 
Continuous surveillance of drinking water sources is crucial for the wellbeing of humans who often suffer from symptoms of arsenicosis caused by consuming arsenic contaminated water on a regular basis. This serious illness is characterized by skin lesions, different forms of cancers, birth defects, and other conditions including premature death (Tomer 2015)

In most of the field testing monitoring programmes, it was observed the field test kits does not give accurate results and mislead the practitioners for wrong decision making. Therefore, In order to guarantee regular drinking water monitoring with accurate results, a test kit based on living, lyophilized bacterial bio reporters emitting bioluminescence as a response to bioavailable arsenic has already been developed. This particular test has been utilized in the field and lab in Germany, Mongolia, Bangladesh, India, Vietnam and Argentina during the past five years. Bio-reporter field measurements of arsenic in ground and surface water were in satisfying agreement with the results of spectroscopic analyses of the same samples conducted in the lab (Tomer 2015). . The results of neglecting this problem and failing to execute regular blanket screenings are manifold and negatively influence health and socio-economic aspects of everyday life (Islam et al, 2012). The main consequence of regularly consuming water containing arsenic is arsenicosis. Skin lesions, a highly increased risk of obtaining cancer, birth defects and even death are some of the correlating clusters of the associated symptoms. There is also a "significant association between maternal arsenic exposure and reduced birth weight" (Rahman et al. 2009), which adds to an increased child mortality rate in developing countries.

\subsection{Arsenic Contamination Management Beyond 2004 - Pakistan}

Inpsite of identification of alarming levels of ground water arsenic contamination and development of national action plan for arsenic contamination, no prudent plans / policies were developed for continuous \& sustainable arsenic contamination monitoring in Pakistan. Due to devoid of continuous monitoring, the arsenic contamination problem in Pakistan is growing, both in scope and complexity and now only in the province of Punjab, 1.3 million people are exposed to drinking water arsenic contamination. Ground water arsenic contamination must be taken as priority pollutant and must be managed with sustainable approaches, based on integrated institutionalized mechanisms.

\section{Literature Review}

Inpsite of implementation of numerous arsenic mitigation programmes and awareness campaigns, still, large numbers of people continue to drink water from the same contaminated water sources, marked red. In Bangladesh, Some other water testing programmes carried out with the aid of community health workers have indicated that community awareness increases as a consequence of the programmes. Therefore, continuing education and monitoring needs to be integrated into existing health services, whether governmental or nongovernmental (Allan $\mathrm{H}$ et al, 2000)

\section{Objectives}

The salient objectives are as under;

1. To review the existing arsenic mitigation interventions in the context of sustainability and programme upscaling in the other arsenic hit areas of Pakistan.

2. To develop sustainable institutional linkages/ strategies for post programme monitoring and impact evaluation practices.

3. To streamline the methods and procedures of water sampling, field testing tools/techniques and validation processes in terms of accuracy \& efficiency for sustainable monitoring processes.

\section{Methodology}

Extensive literature review of arsenic mitigation programmes was carried out by various donor agencies and NGOs (from 1999- 2005/07) in arsenic contamination areas of Pakistan, with a view to ascertain post programme interventions sustainability, monitoring and impact evaluations processes.

Field visits of arsenic contamination affected areas were carried out to meet the effected individuals and communities for post programme arsenic impact evaluations.

Meeting with related government departments were held on monitoring techniques and tools and further up-scaling arsenic mitigation programmes by making it part of annual development plans (ADPs)

\section{Results and Discussion}

\subsection{Review of the Existing Arsenic Mitigation Programme}

Ground water arsenic contamination problems in Pakistan surfaced/indentified in late nineties, followed by various arsenic mitigation interventions and programmes by various donors agencies and government departments \& organizations. The summary of all such measures / review of the arsenic mitigation programmes is as under;

Soon after ground water arsenic contamination revelation in Pakistan, preliminary arsenic testing survey/ investigation was conducted in all the four provinces during 1999-2000. During the investigation, 308 samples were collected from these six potentially high-risk districts, taking one sample each from a grid size of $100 \mathrm{~km}^{2}$. These samples were processed at laboratory using a Hydride Generation Atomic Spectrometer. Analysis of the samples 
revealed that 14 percent had arsenic concentrations of over $10 \mathrm{ppb}$ (WHO guideline value) and three percent (i.e. six samples/sites) above $50 \mathrm{ppb}$ (Pakistan guideline value is 10ppb).

Based on the findings of the preliminary investigations, national survey in 2001 was launched in 35 districts which revealed that revealed that almost 30 percent of samples had arsenic concentrations over $10 \mathrm{ppb}$ and seven percent above $50 \mathrm{ppb}$.

\subsubsection{Arsenic Mitigation Activities - 2002-2004}

Basing on the outcomes of national survey for arsenic contamination in Pakistan, following arsenic mitigation were undertaken;

- Blanket testing/screening of water sources in the four districts (Dadu, Khairpur, Nawabshah, and Tharparkar) in Sindh province that ranked highest in arsenic contamination during the national survey;

- A first round of village-level surveys for arsenic contamination in the three districts (Multan, Rahim Yar Khan, and Bahawalpur) that had ranked highest for arsenic contamination in Punjab, followed by five more districts (DG Khan, Layyah, Muzafar Garh, Sargohda, and Jhang) in Punjab in the second round of focused surveys;

- Blanket testing in Multan, Rahim Khan, and Bahawalpur in Punjab based on results of focused survey;

- Resource integration based, national action plan for arsenic mitigation ( NAPAM) was written in 2004 ( by Col. Islam-ul-Haque) which holistically gave the future directions for arsenic mitigation in Pakistan.

- Arsenic Removal Technology (ART) tanks units (for small communities \& for households levels were designed and installed.

- Social mobilization, advocacy and awareness campaigns were conducted in the affected areas.

\subsubsection{Analysis of Arsenic Mitigation Programmes-Pakistan}

Soon after the identification of arsenic revelation in Pakistan in 1999, tremendous amount of efforts were made for arsenic mitigation, like national arsenic testing surveys, installation of community based arsenic removal units, advocacies, social mobilization and awareness campaigns. These efforts cloud only last for 6-7 years which were primarily dependent on foreign donor's funding. Afterwards, the above mentioned arsenic contamination programmes in Pakistan, could not continued / up-scaled, but virtually have been caped due to the following major reasons;

- Devoid of government buying and ownership, as arsenic mitigation programmes were not made part of annual development programmes (ADPs) by the federal and provincial governments, inpsite of their commitments, made in national plan action for arsenic mitigation. Rather government departments relied on donors agencies funding, like UNICEF etc, which could not be provided.

- Non-implementation of national action plan for arsenic mitigation in true letter \& spirit and national steering committee on arsenic mitigation, as suggested in NAPAM.

- Resultantly, provinces (Punjab \& Sindh) neither made any tangible efforts to activate provincial steering committees and nor the line departments / institutions diverted some financial resources for the continuation of the arsenic mitigation programmes in the respective arsenic hit districts.

- All the installed community based arsenic removal technologies in the affected areas, either have become non-functional or have been damaged/removed.

- Initially, social behaviour change communication strategies were launched only as a onetime measure but not as a sustained process and due to which majority of the people are relying on arsenic contaminated water for their daily needs.

- Now, at this point in time in Pakistan, arsenic mitigation programmes have been shelved and as a result, 1.3 million people are exposed arsenic contamination in the province of southern Punjab only (Centre for Environmental Protection Studies )

\subsection{Sustainability Framework and Institutional Linkages Mechanisms}

Arsenic mitigation programme sustainability, ensures the tangible outcomes and impacts which contributes towards provisioning of arsenic free water to the target communities. Sustainability paradigm must have clearly defined rationales, measures and set of activities to be formed performed by all the stakeholders. In Pakistan, all good intentioned arsenic mitigation programme could not sustained, as discussed earlier, therefore, following programme sustainability framework is suggested for such future programmes, as shown in figure- 2 , below; 


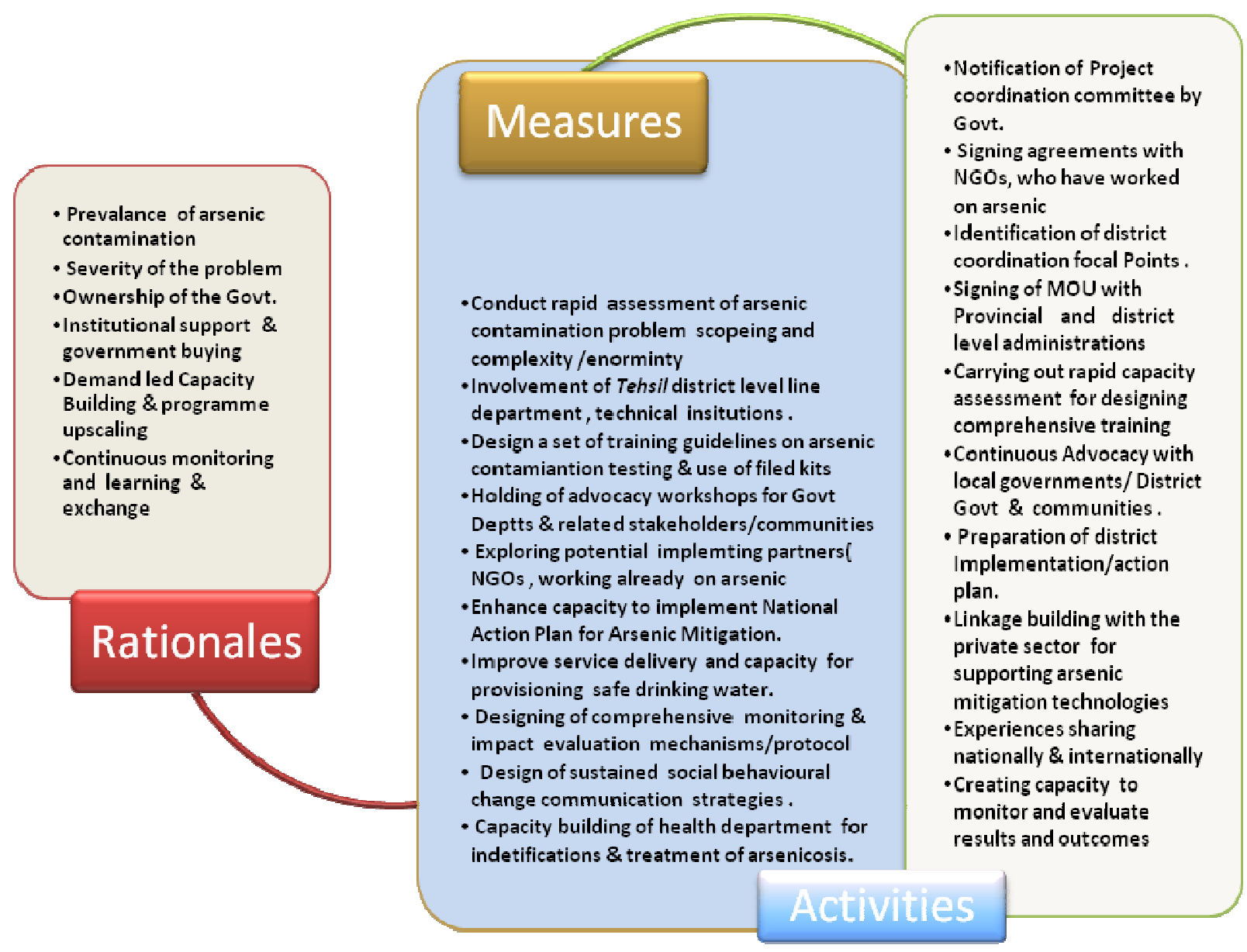

Figure 2. Programme sustainability model framework.

\subsection{Institutional Linkages Path Way Mechanisms for Effective Sustainable Monitoring}

In national action plan for arsenic mitigation did advocate outlines of institutional mechanisms to support arsenic mitigation programmes, but, there was no mention of detailed activities to be performed by each organ of specific institution/department. Devoid of legislation also contributed towards no up-scaling of the arsenic mitigation programmes in Pakistan, as the related government line department did not keep any financial resources in their annual development programmes.

Monitoring and evaluation must be made an essential part of the National Action Plan for Arsenic Mitigation Planning and should be one of the integrated components of the national action plan and linkage to process of programme implementation. The steps taken in this regard include:

a. Establishing a National Action Plan for Arsenic Mitigation (NAPAM) Forum at national, provincial and district levels.

b. Setting up of technical units from Pakistan council of research in water resources (PCRWR) at national, provincial and district levels.

c. Strengthening of NAPAM units to create a database on arsenic contamination related matters.

d. Strengthening and expanding the scope and role of existing Water Quality Management and Information System (WQMIS) and its coordination, if possible, with other district information systems to avoid a top-down approach.

e. Improving the mechanisms and capacity of district management for effective supervision, monitoring and evaluation of Arsenic Mitigation Programmes and projects.

f. Establishing coordinator/support officers at district levels for timely and speedy coordination among the various executing agencies at district levels.

g. Establishing Village Arsenic Mitigation Committees (VAMC) for enhancement of community participation, resource mobilization, monitoring and evaluation at the grassroots level.

h. Indicators for monitoring need to be developed such as behavioural change on use of arsenic -safe water, improved sanitation and hygiene.

i. The monitoring process should also be able to reflect the problems and constraints during programme implementation, solution/supports provided by communities, local government if they are within their capacities.

Therefore, to keep the arsenic mitigation on tracks, following institutional arrangements, at federal levels, is suggested, as shown in figure-3, below; 


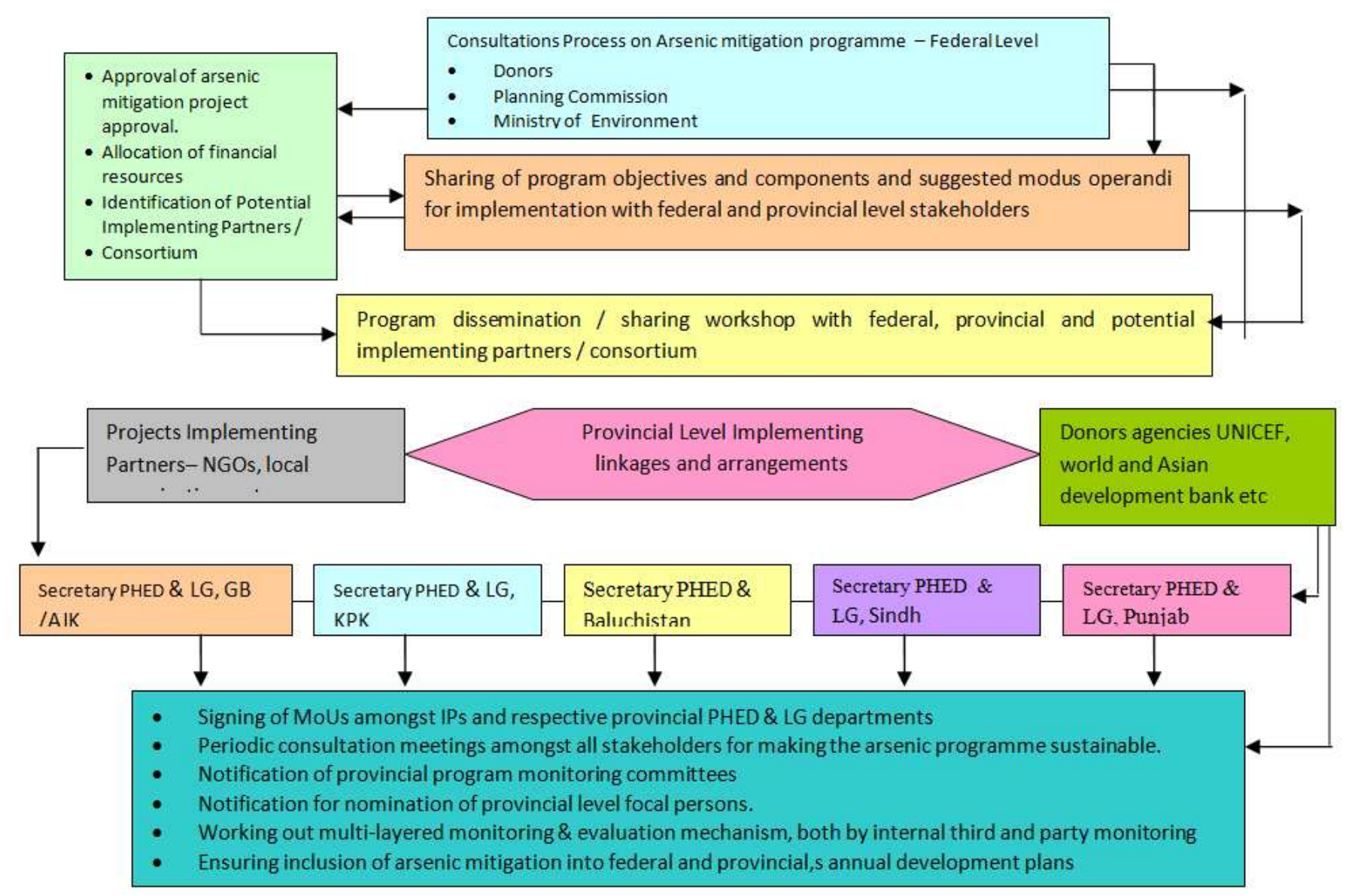

Figure 3. Institutional support mechanisms at federal levels.

\subsubsection{Implementation \& Monitoring Agencies- Roles and Responsibilities}

The following agencies, at district and town levels, will be involved in monitoring and evaluation of the National Action Plan for Arsenic Mitigation.

a. TMAs (Tehsil Municipal Administration) will monitor the execution plan/activities in the field and will ensure their timely completion in stipulated time and space.

b. Assistant Director Local Government (ADLG) in each district will be responsible for monitoring progress achieved against planned targets. ADLGs will review any gray areas and reallocate resources to meet the planned targets.

c. Director General Local Government (DGLG) will monitor and evaluate all the programmes (as identified \& planned) under implementation. DGLGs will also be responsible for reallocation of resources within the districts and will apprise the National Steering Committee for Arsenic Mitigation of the progress of the work in detail.

d. National Steering and provincial Committees for Arsenic Mitigation will monitor, evaluate and review the arsenic mitigation programmes and will hold quarterly progress review meetings for analyzing monitoring and impact evaluation.

e. Pakistan Council of Research in Water Resources (PCRWR) will monitor the existing technologies being used in the field for efficiency and provide the technical support in all of the entire project areas.

f. Provincial/District levels Institutional Arrangements are shown in figure-4, below; 


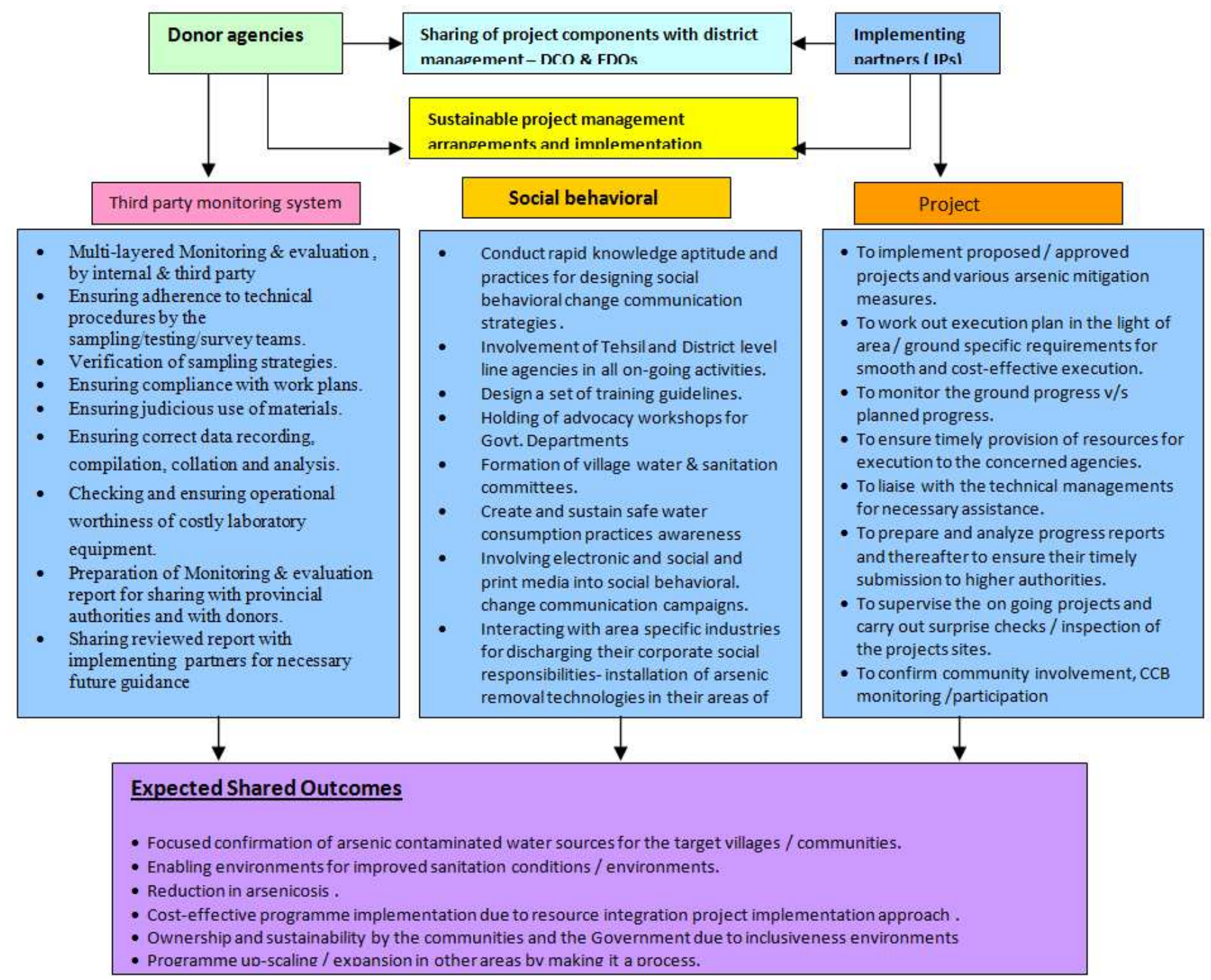

Figure 4. Institutional support mechanisms at federal levels.

\subsubsection{Environmental audit - Monitoring \& Evaluation Tool}

A central Technical Environmental Audit Team (TEAT) shall be formed under the supervision of Director PCRWR, other members will be included in consultation with DGLGs. The envisioned task of the TEAT is:

a. Ensuring adherence to technical procedures by the sampling/testing/survey teams.

b. Verification of sampling strategies.

c. Ensuring compliance with work plans.

d. Ensuring judicious use of materials.

e. Ensuring correct data recording, compilation, collation and analysis.

f. Checking and ensuring operational worthiness of costly laboratory equipment.

\subsubsection{Submission of Progress Reports}

The following progress reports will be submitted:

a. Weekly progress report at Tehsil headquarters level, which will be submitted to District Headquarters.

b. Fortnightly progress report be submitted by District Headquarters to DG Local Government duly compiled by ADLGs.

c. Monthly progress report will be submitted to administrative management (federal level) with a copy to all the tiers of management in the chain.

\subsection{Efficient Arsenic Monitoring -Water Sampling, Testing Equipments and Procedures}

Following arsenic testing techniques, procedures and equipment are suggested, as shown in table-3, below; 
Table 3. Field testing techniques, procedures and equipment for effective monitoring.

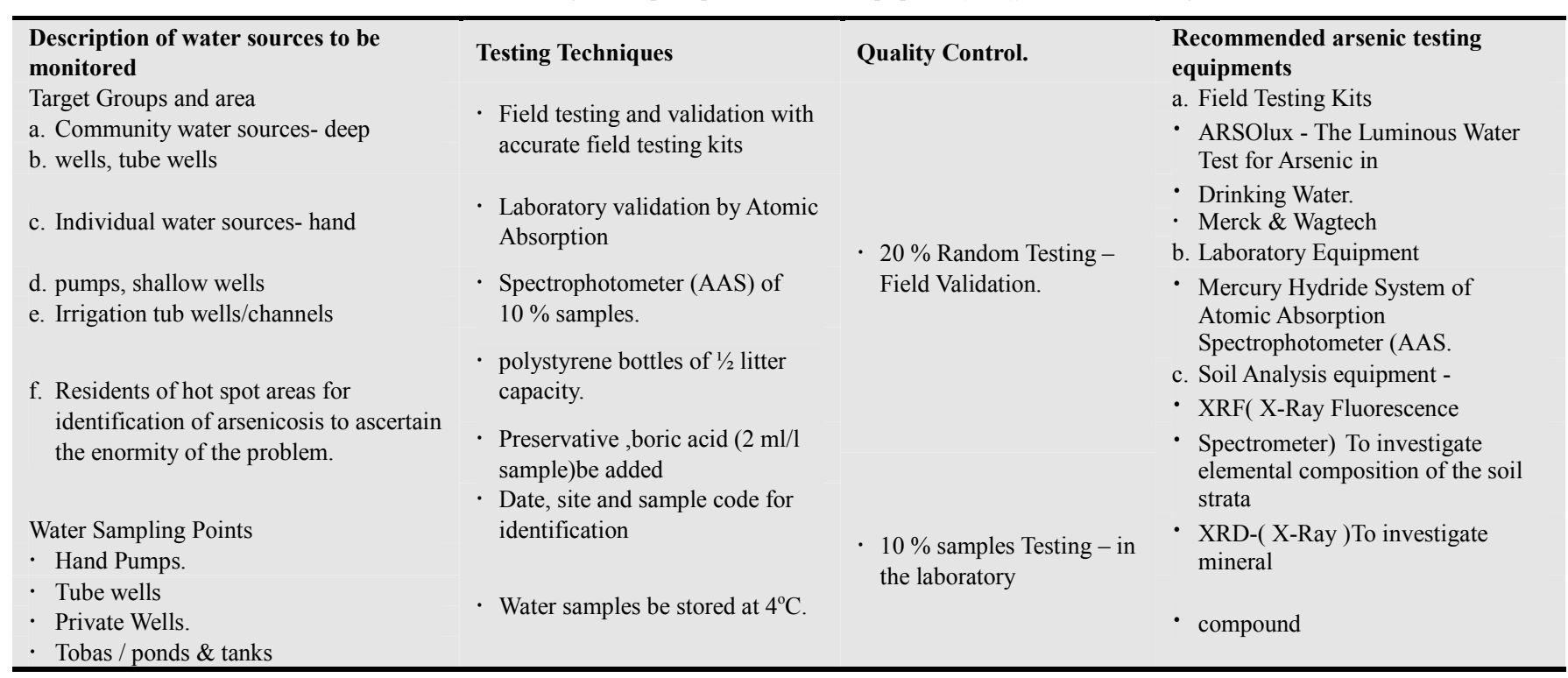

\subsection{Monitoring and Evaluation Logical Frame Work}

All the suggested monitoring and evaluation activities have been summarized in the form of logical frame work, as shown in table-4, below;

Table 4. Logical Frame Work for Arsenic Mitigation Interventions.

\begin{tabular}{|c|c|c|c|}
\hline Objectives & Indicators & Means of Verifications & Assumptions \\
\hline $\begin{array}{l}\text { Goal: } \\
\text { Continuous monitoring of } \\
\text { drinking water sources for the } \\
\text { wellbeing of humans who } \\
\text { often suffer from symptoms } \\
\text { of arsenicosis caused by } \\
\text { consuming arsenic } \\
\text { contaminated water on a } \\
\text { regular basis. Use safe } \\
\text { regular drinking water to } \\
\text { reduce illness and diseases } \\
\text { related to drinking water } \\
\text { arsenic contamination }\end{array}$ & $\begin{array}{l}\% \text { (percentage) reduction related } \\
\text { drinking water arsenic } \\
\text { contamination related diseases } \\
\text { among target population } \\
\text { Arsenic mitigation programme } \\
\text { sustainability, ensures the tangible } \\
\text { outcomes and impacts which } \\
\text { contributes towards provisioning of } \\
\text { arsenic free water to the target } \\
\text { communities. }\end{array}$ & $\begin{array}{l}\text { Reviewed existing arsenic } \\
\text { mitigation interventions in the } \\
\text { context of sustainability and } \\
\text { programme up-scaling in the } \\
\text { other arsenic hit areas of } \\
\text { Pakistan. } \\
\text { Develop sustainable institutional } \\
\text { linkages/ strategies for post } \\
\text { programme monitoring and } \\
\text { impact evaluation practices. } \\
\text { Streamline the methods and } \\
\text { procedures of water sampling, } \\
\text { field testing tools/techniques and } \\
\text { validation processes in terms of } \\
\text { accuracy \& efficiency for } \\
\text { sustainable monitoring } \\
\text { processes. }\end{array}$ & $\begin{array}{l}\text { All stake holders will make sure to } \\
\text { implement MIE system in letter and } \\
\text { spirit. }\end{array}$ \\
\hline $\begin{array}{l}\text { Outcome } 1 \\
\text { Conduct rapid arsenic } \\
\text { contamination problem scope } \\
\text { and complexity /enormity } \\
\text { assessment }\end{array}$ & $\begin{array}{l}\text { Sample water quality tests in each } \\
\text { district confirm that chemical and } \\
\text { bacteriological quality of water } \\
\text { meets national standards in } 90 \% \text { of } \\
\text { cases }\end{array}$ & $\begin{array}{l}\text { Periodic sample surveys and water } \\
\text { quality testing by advisory partners and } \\
\text { M \& E specialist team }\end{array}$ & $\begin{array}{l}\text { Programme retains government interest } \\
\text { and support as well as all stake holders }\end{array}$ \\
\hline $\begin{array}{l}\text { Output } 1.1 \text { Monitoring and } \\
\text { evaluation must be made an } \\
\text { essential part of the National } \\
\text { Action Plan for Arsenic } \\
\text { Mitigation Planning and } \\
\text { should be one of the } \\
\text { integrated components of the } \\
\text { national action plan and } \\
\text { linkage to process of } \\
\text { programme implementation. }\end{array}$ & $\begin{array}{l}\text { Established a National Action } \\
\text { Plan for Arsenic Mitigation } \\
\text { Forum at national, provincial } \\
\text { and district levels. } \\
\text { Set up of technical units from } \\
\text { Pakistan council of research } \\
\text { in water resources (PCRWR) } \\
\text { at national, provincial and } \\
\text { district levels. } \\
\text { Strengthened of NAPAM } \\
\text { units to create a database on } \\
\text { arsenic contamination related }\end{array}$ & $\begin{array}{l}\text { "Community Facility } \\
\text { Inspection" field report } \\
\text { Periodic sample surveys and } \\
\text { water quality testing by advisory } \\
\text { partners, Stake holders and } \\
\text { communities }\end{array}$ & $\begin{array}{l}\text { Line } \\
\text { departments/NGO/Govts/School } \\
\text { s can secure an ongoing supply } \\
\text { of relevant material } \\
\text { No major disputes or conflicts } \\
\text { within the stake holders and } \\
\text { community }\end{array}$ \\
\hline
\end{tabular}




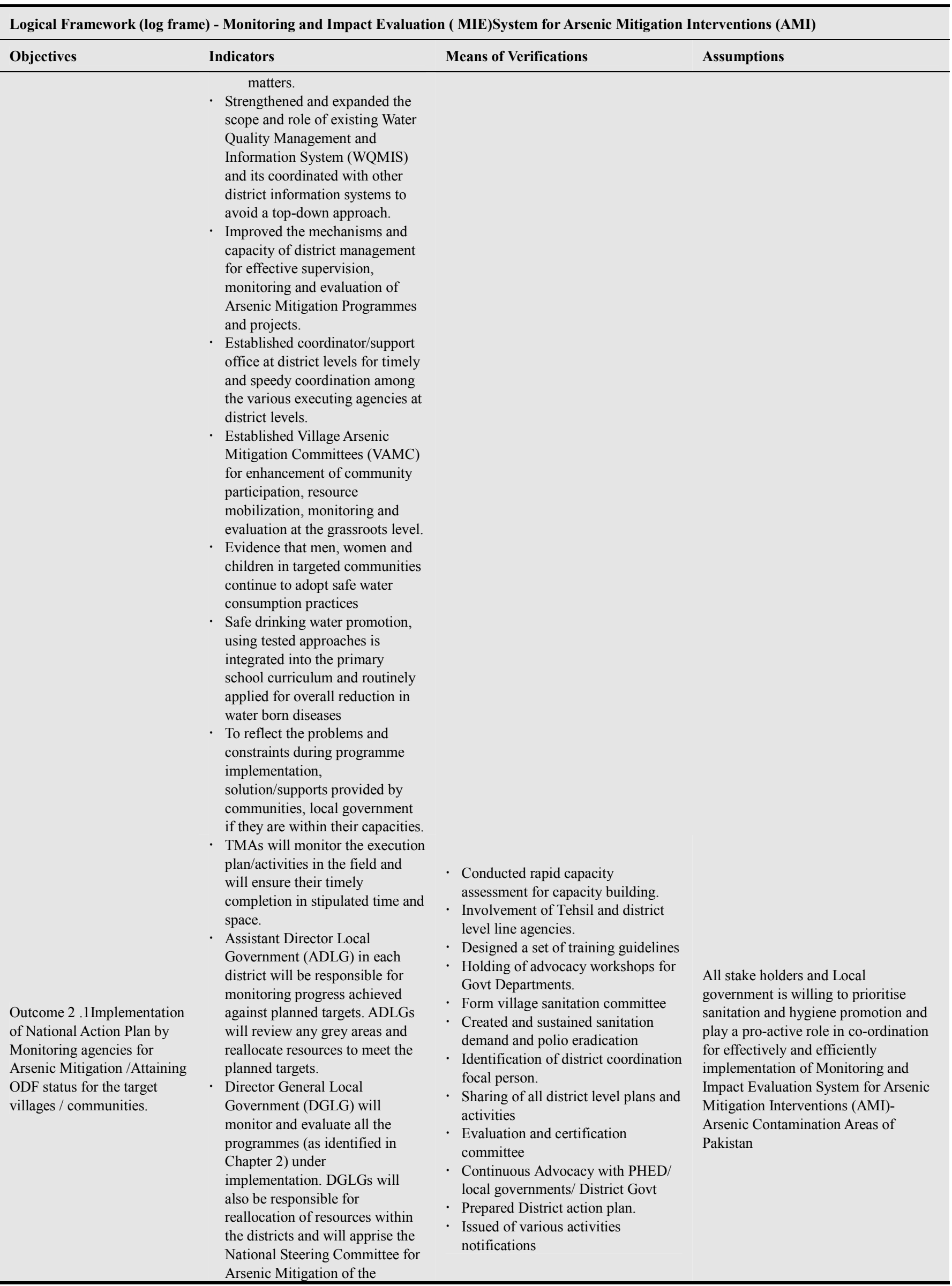




\begin{tabular}{|c|c|c|c|}
\hline \multicolumn{4}{|c|}{ Logical Framework (log frame) - Monitoring and Impact Evaluation ( MIE)System for Arsenic Mitigation Interventions (AMI) } \\
\hline Objectives & Indicators & Means of Verifications & Assumptions \\
\hline $\begin{array}{l}\text { Outcome } \\
3 \text { Environmental audit }\end{array}$ & $\begin{array}{l}\text { progress of the work in detail. } \\
\text { National Steering Committee for } \\
\text { Arsenic Mitigation will monitor, } \\
\text { evaluate and review the arsenic } \\
\text { mitigation programmes and will } \\
\text { hold quarterly progress review } \\
\text { meetings under the chairmanship } \\
\text { of chairman PCRWR. } \\
\text { PCRWR will monitor the } \\
\text { existing technologies being used } \\
\text { in the field for efficiency and } \\
\text { provide the technical support in } \\
\text { all of the entire project areas. } \\
\text { Provincial/District levels } \\
\text { Institutional Arrangements }\end{array}$ & $\begin{array}{l}\text { Weekly progress report at Tehsil } \\
\text { headquarters level, District } \\
\text { Headquarters. } \\
\text { Fortnightly progress report of } \\
\text { District Headquarters to DG Local } \\
\text { Government duly compiled by } \\
\text { ADLGs. } \\
\text { Monthly progress report of } \\
\text { administrative management (federal } \\
\text { level) with a copy to all the tiers of } \\
\text { management in the chain. }\end{array}$ & $\begin{array}{l}\text { Timely submission of report and } \\
\text { validation of data }\end{array}$ \\
\hline $\begin{array}{l}\text { Outputs } 3.1 \text { Ensure adherence } \\
\text { to technical procedures by the } \\
\text { sampling/testing/survey } \\
\text { teams. } \\
\text { Verified sampling strategies. } \\
\text { Ensured compliance with } \\
\text { work plans. } \\
\text { Ensured judicious use of } \\
\text { materials. } \\
\text { Ensured correct data } \\
\text { recording, compilation, } \\
\text { collation and analysis. } \\
\text { Checked and ensured } \\
\text { operational worthiness of } \\
\text { costly laboratory }\end{array}$ & $\begin{array}{l}\text { Adherence of all procedures by } \\
\text { stake holders }\end{array}$ & $\begin{array}{l}\text { Regular analysis and periodic } \\
\text { verification of programme reports }\end{array}$ & $\begin{array}{l}\text { Timely submission of report and } \\
\text { validation of data }\end{array}$ \\
\hline $\begin{array}{l}\text { Outputs3.2 Efficient Arsenic } \\
\text { Monitoring -Water Sampling, } \\
\text { Testing Equipment's and } \\
\text { Duties }\end{array}$ & $\begin{array}{l}\text { Field testing and validation with } \\
\text { accurate field testing kits } \\
\text { - Laboratory validation by Atomic } \\
\text { Absorption Spectrophotometer } \\
\text { (AAS) of } 10 \% \text { samples. } \\
\text { - Polystyrene bottles of } 1 / 2 \text { litter } \\
\text { capacity. } \\
\text { - Preservative ,boric acid ( } 2 \mathrm{ml} / 1 \\
\text { sample)be added } \\
\text { - Date, site and sample code for } \\
\text { identification } \\
\text { - Water samples be stored at } 4^{\circ} \mathrm{C} \text {. }\end{array}$ & $\begin{array}{l}\text { Community water sources- deep wells, } \\
\text { tube wells } \\
\text { Individual water sources- hand pumps, } \\
\text { shallow wells } \\
\text { Irrigation tub wells/channels } \\
\text { Residents of hot spot areas for } \\
\text { identification of arsenicosis to ascertain } \\
\text { the enormity of the problem. } \\
\text { Water Sampling Points } \\
\text { Hand Pumps. } \\
\text { - Tube wells } \\
\text { Private Wells. } \\
\text {. Tobas / ponds \& tanks }\end{array}$ & $\begin{array}{l}\text { To ensure to maintain - } 20 \% \text { Random } \\
\text { Testing -Field Validation. } \\
\text { To ensure to maintain - } 10 \% \text { samples } \\
\text { Testing - in the laboratory }\end{array}$ \\
\hline
\end{tabular}

\subsection{Arsenic Field Testing Kits}

The biggest problems, being faced during the arsenic contamination field testing is the inaquracy of results which mislead for future planning due to non-branded field testing kits. Therefore, to avoid this situation, following field test kits are recommended;

\subsubsection{Merck \& Wagtech Field Arsenic Testing Kit}

Following brands of arsenic field testing are available with the field teams of Arsenic survey funded by UNICEF Pakistan and the same are in use for carrying out field testing, as shown in figure- 5, below; 


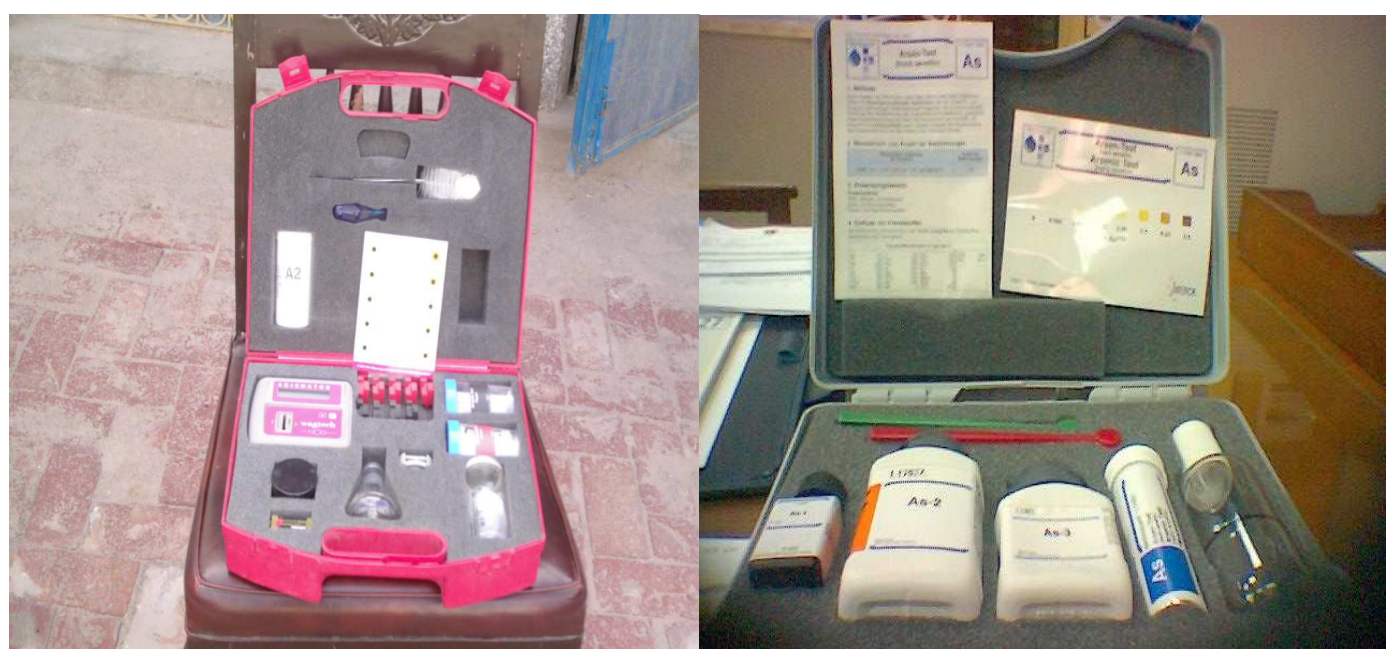

Figure 5. Merck \& Wagtech Field Arsenic testing kit for effective field testing.

\subsubsection{ARSOlux - Arsenic Field Testing Kit}

ARSOlux is a robust, precise and easy to handle biosensor, which serves as a sustainable and efficient field and lab test. It enables fast and parallel screenings of large numbers of drinking water samples for arsenic with low material expenditure. The biosensor emits light when brought into contact with arsenic dissolved in water. The bioluminescence of the non-pathogenic, genetically modified bio-reporter bacteria E.coli DH5 $\alpha$ is detected by the portable measuring device AQUA-CHECK3. The quantifiable light intensity correlates with the arsenic concentration in the water sample. Integrated software stores test results and GPS data for each measurement.In order to guarantee regular drinking water monitoring, even for people belonging to low socioeconomic classes, a test kit based on living, lyophilized bacterial bio--reporters emitting bioluminescence as a response to bioavailable arsenic was developed. This particular test has been utilized in the field and lab in Germany, Mongolia, Bangladesh, India, Vietnam and Argentina during the past five years. Bio-reporter field measurements of arsenic in ground and surface water were in satisfying agreement with the results of spectroscopic analyses of the same samples conducted in the lab. Various activites, being performed with ARSOlux field test kits are shown in figure-6, below;

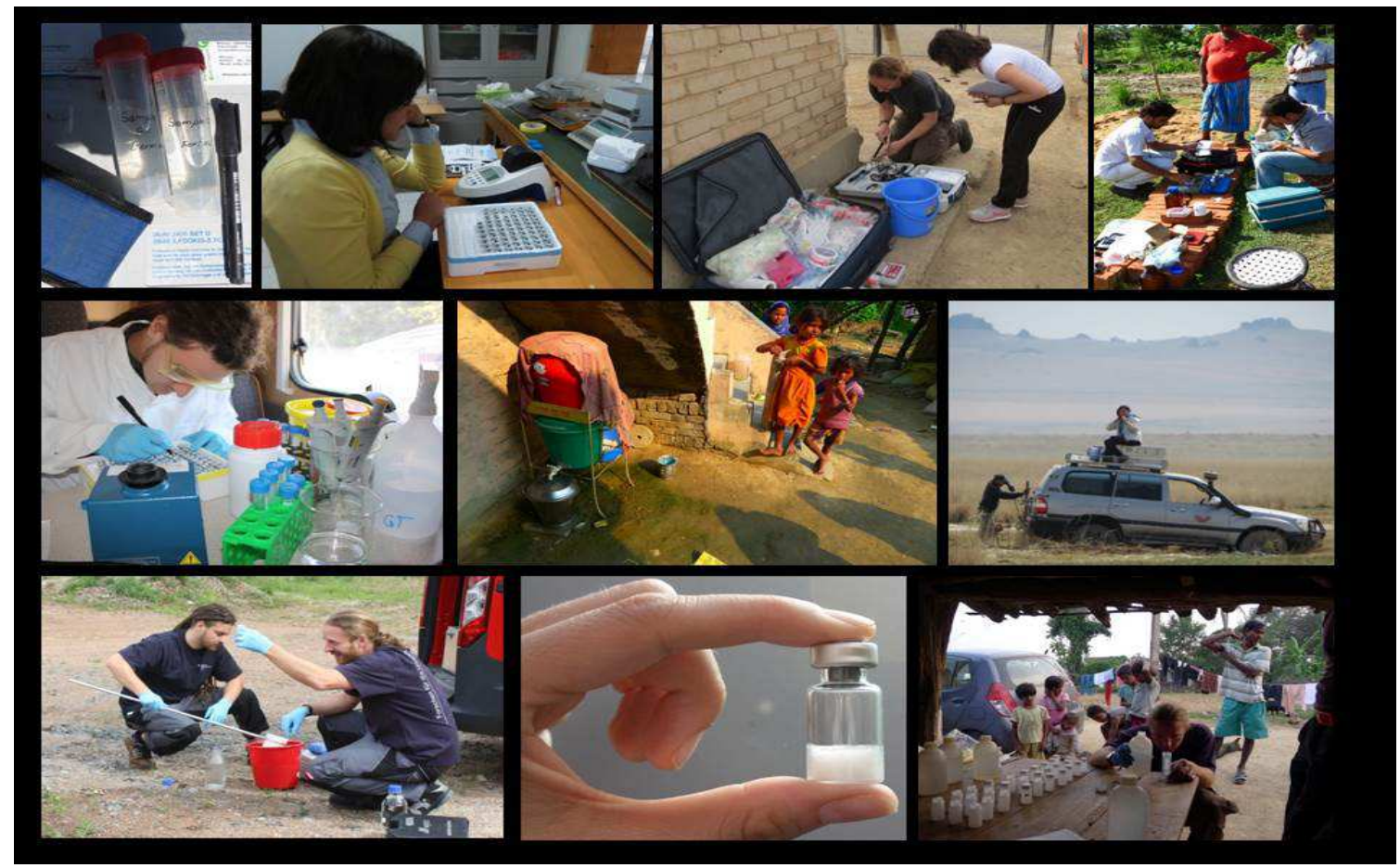

Source: http://www.ufz.de/arsolux

Figure 6. Field Arsenic testing activities with ARSOlux. 


\subsubsection{Arsenic Quick ${ }^{\mathrm{TM}}$ II, 50 Tests and 481303-5-Arsenic Quick ${ }^{\mathrm{TM}}$ II Mini, 5 Tests}

Arsenic Quick II Mini for water quality testing was designed to give the user accurate results without sacrificing cost and time. Designed using cutting-edge chemistry, Arsenic Quick II Mini reports results in only 14 minutes.

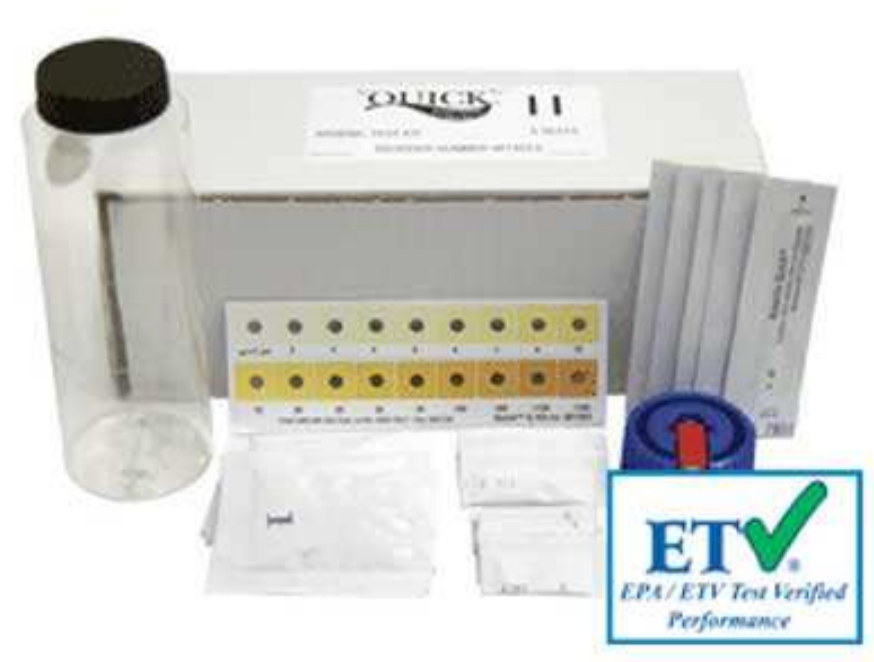

Additionally, there are no dangerous chemicals needed to run this water quality test kit. With only 3 simple test procedures, Arsenic Quick II Mini is a must for any lab, water testing professional, or service technician who values accurate, rapid results without sacrificing cost, which takes only 14 Minutes for the entire tests, as shown in figure-7, below;

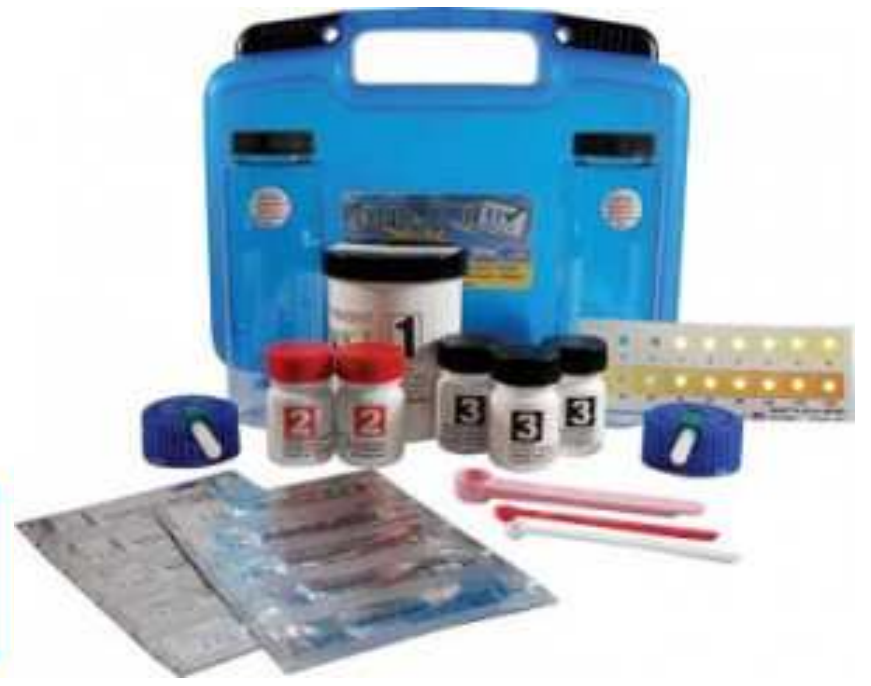

Source: http://arsenickits.com/

Figure 7. Part No. 481303 and Part No. 481303-5 arsenic field testing kits.

\section{Conclusion}

Ground water arsenic contamination has emerged as a big nuisance to public health which adversely impacts the human health and approximately over 137 million people are exposed to this menace. Inpsite of all its lethal impacts, arsenic mitigation programmes could not get requisite government buying and ownership and fragmented efforts have been made or being made, particularly in developing countries, to mitigate this deadly contaminant, that too by the NGOs, financed by donor agencies only. Sustained monitoring and impact evaluation is major missing component which overshadows piece meal arsenic mitigation programmes. Prudent and efficient institutional arrangements at federal, provincial and district levels can ensure effective, sustainable and cost-effective mitigation planning and implementation. Periodic arsenic testing \& monitoring will make the mitigation programmes more result oriented and long lasting, with reliable and accurate, both field \& laboratory equipments. Since ground water arsenic contamination is natural process, therefore, all the such arsenic mitigation programmes must be transformed into natural processes and must not end-up at any point in time.

\section{References}

[1] Allan H. Smith, 1 Elena O. Lingas, 2 \& Mahfuzar Rahman3 Bulletin of the World Health Organization, 2000, 78 (9).

[2] Islam ul Haque (2012), Socio-economic Impacts on Human Life in Arsenic Affected Area of Basti Rasul Pur, Rahim Yar Khan, Pakistan, Sustainable Agriculture Research; Vol. 1, No. 2; 2012 ISSN 1927-050X E-ISSN 1927-0518 Published by Canadian Center of Science and Education.

[3] NAPAM (2005), National Action Plan for Arsenic Mitigation published by Ministry of Climate Change, Government of Pakistan.

[4] Rahman A, Vahter M, Smith AH, Nermell B, Yunus M, El Arifeen S, et al. Arsenic exposure during pregnancy and size at birth: a prospective cohort study in Bangladesh. Am J Epidemiol.2009;169(3):304-312.

[5] Tameez (2004), Arsenic an emerging 1ssue: experiences from Pakistan (30th WEDC International conference, Vietinae, Lao PDR, 2004) Toor, S. N. A. Tahir. "Study of Arsenic Concentration Levels in Pakistani Drinking.

[6] Tomer (2015), The Luminous Water Test for Arsenic in Drinking Water, $7^{\text {th }}$ World Water Forum 2015, Korea.

[7] Unicef (2008), Evaluation of Arsenic Mitigation in Four Countries of the Greater Mekong Region Final Report December 2008, Supported by the Australian Government, AusAID. 